\title{
Food Safety: Play It Safe With Eggs ${ }^{1}$
}

Linda B. Bobroff and Jennifer Hillan²

Fresh eggs may contain bacteria that can cause salmonellosis. This foodborne illness causes vomiting and diarrhea. It can be severe and even fatal in older adults. Reduce your risk for this foodborne illness by following these guidelines.

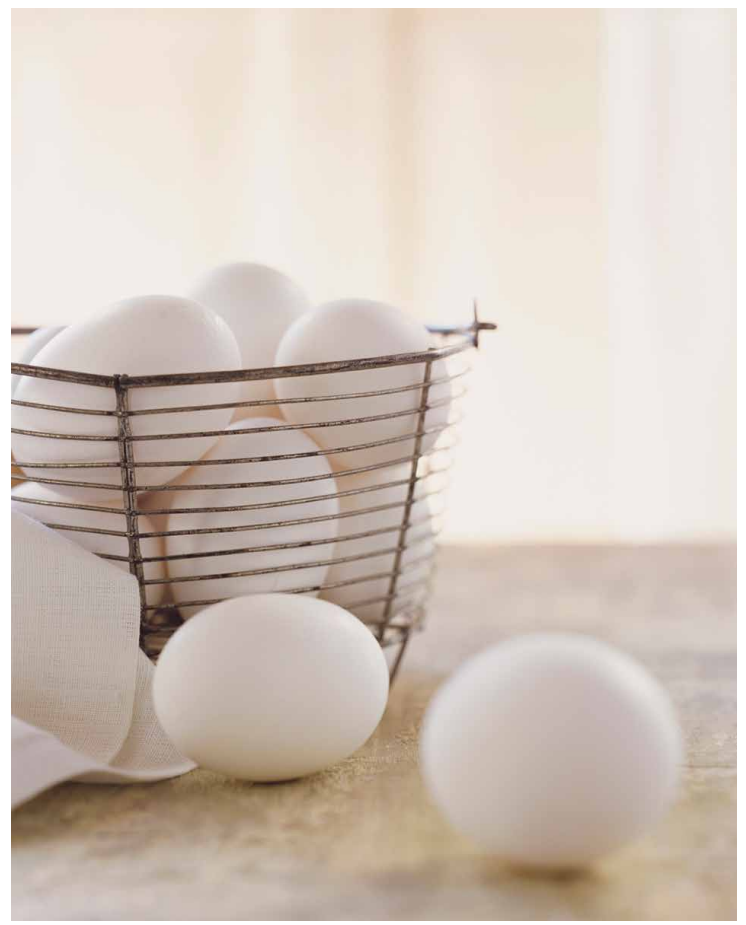

Figure 1. Purchase eggs before the date on the carton. Store them in the carton in the coldest part of the refrigerator for no more than five weeks.

Credits: Digital Vision

\section{Use Eggs Safely}

- Don't buy cracked eggs.

- Purchase eggs before the date on the carton and use within three to five weeks.

- Refrigerate raw eggs right after buying them. Keep them in the original carton in the coldest part of the refrigerator.

- Cook eggs until both the yolk and white are firm. Scrambled eggs should not be runny.

- Cook casseroles and other egg dishes to $160^{\circ} \mathrm{F}$.

- Do not eat foods made with raw or lightly cooked eggs, such as homemade ice cream, Caesar salad dressing, or hollandaise sauce; they can make you sick. You can use pasteurized eggs in recipes that include raw eggs so that the foods are safe to eat.

\section{What About Leftovers?}

- Use hard-cooked eggs within one week after cooking.

- Refrigerate leftover egg dishes right away and use within three days.

- Reheat leftover egg dishes to $165^{\circ} \mathrm{F}$ before eating.

1. La versión español de este documento es Seguridad Alimentaria: Juegatela seguro con los huevos (FCS8635-Span). This document is FCS8635, one in a series of the Department of Family, Youth and Community Sciences, UF/IFAS Extension. First published: February 2000. Latest revision: June 2013. Please visit the EDIS website at http://edis.ifas.ufl.edu.

2. Originally written by Jennifer Hillan, MSH, RD, LD/N, former ENAFS nutrition educator; revised by Linda B. Bobroff, PhD, RD, LD/N, Department of Family, Youth and Community Sciences; UF/IFAS Extension, Gainesville, FL 32611. 